\title{
Autoamputation of the fifth digit: ainhum (dactylolysis spontanea)
}

\section{Garry Shtofmakher, ${ }^{1}$ Michelle Ashley Kaufman, ${ }^{2}$ Randy Cohen, ${ }^{3}$ Aaron Glockenberg ${ }^{1}$}

${ }^{1}$ New York College of Podiatric Medicine, New York,

New York, USA

${ }^{2}$ New York College of Podiatric Medicine, Brooklyn, New York, USA

${ }^{3}$ Department of Radiology, New York College of Podiatric Medicine, New York,

New York, USA

\section{Correspondence to}

Garry Shtofmakher,

gshtofmakher@nycpm.edu

Accepted 23 April 2014
CrossMark

\footnotetext{
To cite: Shtofmakher G, Kaufman MA, Cohen $\mathrm{R}$, et al. BMJ Case Rep Published online: [please include Day Month Year] doi:10.1136/bcr-2014205021
}

\section{DESCRIPTION}

Ainhum (dactylolysis spontanea) is an idiopathic condition that involves a 'band-like' soft tissue constriction of a digit. ${ }^{1}$ This pathology often presents bilaterally with the greatest prevalence on the fifth digit. ${ }^{1}$ Dark-skinned individuals of African, Asian,
West Indian, North, South and Central American decent have been found to present with ainhum. ${ }^{1}$ Clinical diagnosis includes at least one of the three following criteria: soft tissue constriction, bulbous enlargement of the toes and thinning or lysis of phalangeal bones, in addition to radiographic
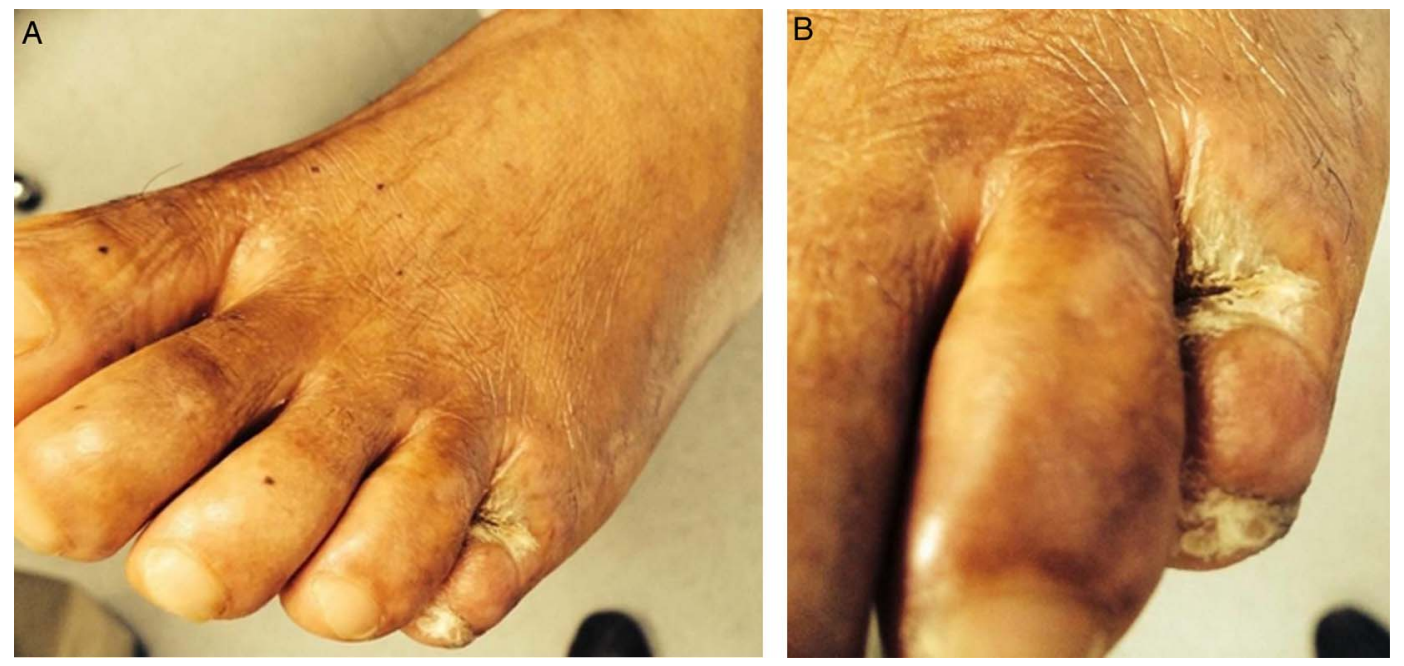

Figure 1 (A) Clinical presentation of ainhum with 'band-like' constriction of the left fifth digit. (B) Close-up clinical presentation of ainhum of the left fifth digit.
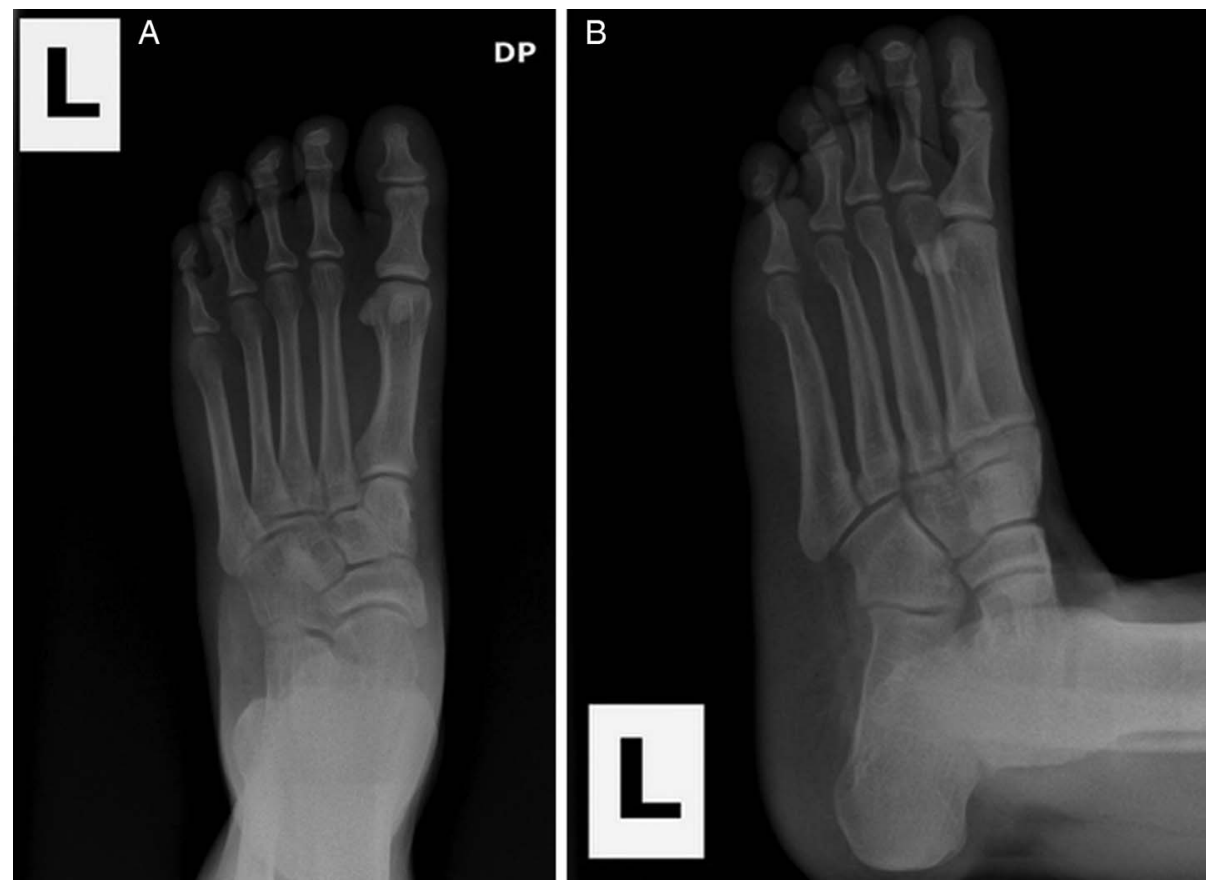

Figure 2 (A) Anteroposterior weight bearing view of the left foot indicating Cole grade III ainhum with bone involvement of the proximal phalanx. (B) Medial oblique weight bearing view of the left foot indicating 'band-like' constriction of the fifth digit at the level of the head of the proximal phalanx. 
confirmation. ${ }^{1}$ Grading consists of four stages. Grade I in which there is just a groove with no visible swelling or osseous involvement; grade II in which there is bulbous enlargement of the digit distally, with external rotation; in grade III there is osseous involvement and grade IV when autoamputation has occurred. ${ }^{2}$ Conservative therapy includes topical or injectable corticosteroids, salicylate preparations or retinoids. ${ }^{3}$ Surgical intervention consists of Z-plasty for grade I and early grade II; amputation for all other cases. ${ }^{1}$

A 43-year-old African native presented to the clinic with a painful left foot. Pain is worse on ambulation and throbbing at night. The patient's medical history and family history are unremarkable. Neurovascular status is intact. A constrictive band was present around the head of the proximal phalanx of the left fifth digit (figure 1) with pain on range of motion. Radiographs were taken (figure 2) indicating grade III ainhum. The patient was initially placed on oral naproxen. The patient presented 2 weeks later with increased pain. Triamcinolone-10 and $1 \%$ lidocaine were injected into the area.

\section{Learning points}

- Ainhum presents as a soft tissue constriction of the digits and can lead to autoamputation.

- Treatment of ainhum consists of either conservative or surgical approaches depending on the grade.

- The true etiology of Ainhum is still unknown.

Competing interests None.

Patient consent Obtained.

Provenance and peer review Not commissioned; externally peer reviewed.

\section{REFERENCES}

1 Daccarett M, Espinosa G, Rahimi F, et al. Ainhum (dactylolysis spontanea): a radiological survey of 6000 patients. J Foot Ankle Surg 2002;41:372-8.

2 Toney PA, Mandi DM, Mandracchia VJ. Congenital transverse deficiencies: bilateral presentation of the foot. Clin Podiatr Med Surg 2006;23:761-7, vii.

3 Dasari BV, McBrearty A, Lau L, et al. Pseudoainhum of the toe with underlying chronic lower-limb ischemia. Int J Low Extrem Wounds 2011;10:96-7.

Copyright 2014 BMJ Publishing Group. All rights reserved. For permission to reuse any of this content visit

http://group.bmj.com/group/rights-licensing/permissions.

BMJ Case Report Fellows may re-use this article for personal use and teaching without any further permission.

Become a Fellow of BMJ Case Reports today and you can:

- Submit as many cases as you like

- Enjoy fast sympathetic peer review and rapid publication of accepted articles

- Access all the published articles

- Re-use any of the published material for personal use and teaching without further permission

For information on Institutional Fellowships contact consortiasales@bmjgroup.com

Visit casereports.bmj.com for more articles like this and to become a Fellow 